\title{
Analysis of Affecting Factors to the Regional Growth and Poverty Rate in Indonesia:
} Applying the Heterogeneous Regression*

\author{
Dodik Siswantoro, Tien Mulyanthi \\ Universitas Indonesia, Depok, Indonesia
}

\begin{abstract}
Effective regional budget may significantly affect the development of province in Indonesia. Subsidy from central government heavily composed in regional budget. This shows low real regional income which means districts are still depending on budget from central government in general. This research aims to analyze some local factors that affect the regional growth and poverty in 28 provinces in Indonesia. Data panel and heterogeneous regression would be employed in the research. Real regional income, transfer revenue, and labor are the most significant factors to regional growth differently, but it has a different sign as well as the poverty rate. Heterogeneous regression may give better model analysis than the simple one.
\end{abstract}

Keywords: budget, regional, growth, poverty, government

\section{Introduction}

Indonesia governmental system has shifted to decentralization after the reformation era in 1998. It emphasized the regional autonomy development, which supported by Act No. 22/1999 on regional autonomy then replaced by Act No. 32/2004 which strengthens on regional budget relocation and full authority in the regional system. Other supported and related regulations were also issued in order to be applied in decentralization implementation.

This shift should faster affect the regional development than previous system as they have more powerful budget authority. The amount of regional budget is increased in order to accelerate its development. Besides the revenue transfer from central government, region would have the real regional income (known as Pendapatan Asli Daerah-PAD) to be allocated fully to the region. This would motivate local government to find ideas and solutions as how to increase their income source from real regional income. Indirectly, by having the income source increase in the region, will increase economic growth then should reduce the poverty rate in each region as the implication.

\footnotetext{
* Authors would like to gratitude to Prof. I Gusti Ngurah Agung for suggesting the appropriate model of the research and anonymous audiences for concise suggestions at 3rd International Conference on Business and Economic Research 2012, Bandung, Indonesia.

Dodik Siswantoro, SE Ak MSc ACC, Public sector accounting and Islamic accounting, Universitas Indonesia.

Tien Mulyanthi, SE, Public sector accounting, Universitas Indonesia.

Correspondence concerning this article should be addressed to Dodik Siswantoro, Fakultas Ekonomi Universitas Indonesia Kampus UI Depok Indonesia 16424. E-mail: dodik.siswantoro@ui.ac.id; tien_mulyanthi@yahoo.com.
} 
This paper tries to analyze some factors that affect the regional economic growth. Those identified factors such as real income region, transfer, labor would be main factors in this case. Then, the effect on poverty rate in the region is also analyzed further. The structure of the paper first, explains previous researches which analyze some factors that affect economic growth, then the poverty rate. Second, it constructs the model with heterogeneous and simple approach as well as the sample including the filter data. At last, analysis is in comparing the application of heterogeneous and simple regression for the model.

\section{Supporting Theory}

Indrawan (2011) identified that regional budget had an effective tool to support activities in region. This is because all activities are regulated and supported by the budget. The bigger the budget is, the more activities can be conducted, which will create higher economic activities as well as the growth and reduce the poverty rate indirectly.

Economic theory stated that the economic growth shows more output being produced, which indicates more people will work, so it should decrease the poverty in the region as more people will have income. Wijayanto (2010) emphasized that growth and poverty had close correlation because at the beginning of development process, the poverty was quite high then at the end, the poverty was being lower.

Previous researchers have done some researches related with this topic, they are Omposungu (2010), Hamzah (2007), Palupi (2009), Pusporini (2006), and Kaspuri (2007). Each researcher applies a different model. Thus, in this paper the authors try to adopt only significant variables. Finally, real regional income, transfer, and labor are applied in the model. Other theory and research which analyze the relationship between some variables to economic growth, and economic growth to poverty rate can be seen in Table 1. Siregar and Wahyuniarti (2007) analyzed the economic growth affected the poverty rate. Thus, the authors try to propose hypothesis if these variables may also have direct effect on poverty rate.

Table 1

Factor Affecting the Economic Growth and Poverty Rate

\begin{tabular}{|c|c|c|c|c|}
\hline No & Independent variable & Dependent variable & Researcher & Result \\
\hline \multirow[t]{4}{*}{1} & Real regional income & Economic growth & Omposungu (2010) & + \\
\hline & & & Palupi (2009) & + \\
\hline & & & Hamzah (2009) & $\mathrm{DAU}+, \mathrm{DAK}-$ \\
\hline & & & Pusporini (2006) & + \\
\hline \multirow[t]{4}{*}{2} & Transfers & Economic growth & Omposungu (2010) & + \\
\hline & & & Palupi (2009) & + \\
\hline & & & Hamzah (2009) & - \\
\hline & & & Pusporini (2006) & + \\
\hline \multirow[t]{2}{*}{3} & Labor & Economic growth & Palupi (2009) & + \\
\hline & & & Kaspuri (2007) & + \\
\hline 4 & Economic growth & Poverty rate & $\begin{array}{l}\text { Siregar \& Wahyuniarti } \\
(2007)\end{array}$ & + \\
\hline
\end{tabular}

Factors that affect regional economic growth are:

(1) Real regional income

It is an original revenue which comes from local source of region. Based on Act No. 33/2004, regional real 
income is taken by regional government based on related regulation. It comprised of regional tax, retribution, and regional owned company income.

(2) Transfer

Based on government regulation No. 24/2005, transfer is comprised of transfer from central government-balanced (sharing fund, general allocation fund (DAU), specific allocation fund (DAK), and other provinces). It is from national budget or other central government in the case of decentralization.

(3) Labor

Palupi (2009) and Kaspuri (2007) highlighted that labor significantly affected the economic growth in Indonesia.

Then, hypotheses in this research are:

H1: Real regional income has positive significant effect on regional economic growth/poverty rate.

$\mathrm{H} 2$ : Transfer has positive significant effect on regional economic growth/poverty rate.

H3: Labor has positive significant effect on regional economic growth/poverty rate.

\section{Research Methodology}

The research applies regression model using data panel. Sample is from all provinces in Indonesia from 2008 to 2010, in which data are taken from Statistics Bureau, Ministry of Manpower and Transmigration and Audit Board (see Table 2).

Table 2

Data Sample

\begin{tabular}{ll}
\hline Description & Total \\
\hline Financial report & 33 \\
Under review & -5 \\
Available data & 28 \\
Total 2008, 2009, 2010 & 84 \\
\hline
\end{tabular}

Model that is tested to show some factors that affect the regional economy growth is:

$$
\begin{gathered}
\operatorname{PDRB}_{\mathrm{it}}=\alpha_{1} \mathrm{PAD}_{\mathrm{it}} *(\mathrm{~T}=1)+\alpha_{2} \mathrm{PAD}_{\mathrm{it}} *(\mathrm{~T}=2)+\alpha_{3} \mathrm{PAD}_{\mathrm{it}} *(\mathrm{~T}=3)+\alpha_{4} \mathrm{TRAN}_{\mathrm{it}} *(\mathrm{~T}=1)+\alpha_{5} \mathrm{TRAN}_{\mathrm{it}} *(\mathrm{~T}=2)+ \\
\alpha 6 \mathrm{TRAN}_{\mathrm{it}} *(\mathrm{~T}=3)+\alpha 7 \mathrm{TK}_{\mathrm{it}} *(\mathrm{~T}=1)+\alpha 8 \mathrm{TK}_{\mathrm{it}} *(\mathrm{~T}=2)+\alpha 9 \mathrm{TK}_{\mathrm{it}} *(\mathrm{~T}=3)+\alpha 10^{*}(\mathrm{~T}=1)+\alpha 11 *(\mathrm{~T}=2)+\alpha 12 *(\mathrm{~T}=3)(1)
\end{gathered}
$$

Then the effect on poverty rate also is investigated:

$$
\begin{gathered}
\operatorname{MISK}_{\mathrm{it}}=\alpha_{1} \mathrm{PAD}_{\mathrm{it}}^{*}(\mathrm{~T}=1)+\alpha_{2} \mathrm{PAD}_{\mathrm{it}}{ }^{*}(\mathrm{~T}=2)+\alpha_{3} \mathrm{PAD}_{\mathrm{it}} *(\mathrm{~T}=3)+\alpha_{4} \mathrm{TRAN}_{\mathrm{it}}^{*}(\mathrm{~T}=1)+\alpha_{5} \mathrm{TRAN}_{\mathrm{it}} *(\mathrm{~T}=2)+ \\
\alpha 6 \mathrm{TRAN}_{\mathrm{it}} *(\mathrm{~T}=3)+\alpha 7 \mathrm{TK}_{\mathrm{it}} *(\mathrm{~T}=1)+\alpha 8 \mathrm{TK}_{\mathrm{it}} *(\mathrm{~T}=2)+\alpha 9 \mathrm{TK}_{\mathrm{it}} *(\mathrm{~T}=3)+\alpha 10 *(\mathrm{~T}=1)+\alpha 11 *(\mathrm{~T}=2)+\alpha 12 *(\mathrm{~T}=3)(2)
\end{gathered}
$$

Operational variables in this research are:

(1) PDRB is regional economic growth. The data are based on constant price of 2000 in percentage. The data are taken from Biro Pusat Statistik (BPS);

(2) PAD is real regional income (based on realization in IDR). It is called as Pendapatan Asli Daerah (PAD). The data are transformed into natural $\log (\ln )$ in order to be comparable. Data are taken from Audit Board;

(3) TRAN is income transferred from central government. The data are also transformed into natural log (ln) in order to be comparable. Data are taken from Audit Board;

(4) TK is labor in each region. The data are also transformed into natural $\log (\ln )$ in order to be comparable. 
The data are taken from Ministry of Manpower and Transmigration;

(5) MISK is poverty rate in percentage. The data are taken from Biro Pusat Statistik (BPS).

\section{Analysis}

The descriptive result shows various data as they are caused by inherent different characteristics for each region in Indonesia. For example, the highest regional economy is up to $22.74 \%$, while the lowest is $-2.65 \%$, which is supported by the high deviation standard. It also occurs for the PAD, TRAN, TK, and MISK. The big difference between the lowest and the highest shows that there are striking gaps among provinces in Indonesia (see Table 3). Analysis for each region must be compared by its regional budget to get better and fair comprehension.

Table 3

Descriptive Statistics

\begin{tabular}{lccccc}
\hline & PDRB (\%) & PAD (Rp bn) & TRAN (Rp bn) & TK (mn) & MISK (\%) \\
\hline Mean & 6.41 & $1,669.20$ & $1,557.53$ & 4.58 & 14.28 \\
Median & 5.85 & 713.19 & 827.52 & 2.27 & 12.43 \\
Max & 22.74 & $12,891.99$ & $10,133.99$ & 30.83 & 37.53 \\
Min & $(2.65)$ & 42.51 & 422.06 & 0.46 & 3.48 \\
SD & 3.48 & $2,472.98$ & $1,841.09$ & 6.42 & 7.35 \\
\hline
\end{tabular}

Note. Source: From the authors'own data

The first model analyzes the factors that affect the regional economic growth in each region. It applied panel least squares method with heterogeneous regression. The reason of applying heterogeneous regression is that independent variables have significant different effect on dependent variable for each year, which shows by wald-test analysis (see Tables 5, 6, and 7). Thus, the authors ignored the fixed/random effect method for the same reason (Agung, 2006).

There is no consistent sign for each variable, TRAN and TK show the same sign but not for the PAD. The most significant variable is TRAN for 5\% in the first year and the second year, then $10 \%$ for the third year. Followed by PAD (significant for 5\% in second year and $10 \%$ for the first year), then TK is only significant for the second year (in 5\%). TRAN may be the significant factor to the PDRB, and then followed by PAD then TK. TK has smallest effect on the PDRB (see Table 4).

For the time frame, second year has the most significant variable (in 5\%), followed by the first year ( $5 \%$ for TRAN and $10 \%$ for PAD). The third year is only significant for TRAN in $10 \%$. From this, the result shows that the second year has a better result, followed by the first then the third year.

When the authors tested using simple panel data regression, all variable are insignificant. Only PAD show positive signs.

The similar signs from model 1 with model 2 are on PAD (2nd year), TRAN (2nd year) and TK (2nd year). Model 1 should create factors in positive signs as it supports the PDRB, and is opposite to model 2 (ideally). The amount of PAD, TRAN, and TK should increase or have positive effect on regional growth (PDRB). The problems of inconsistent results existed may be caused by financial global crisis. Thus, PAD in model 2 have the ideal signs to MISK, but not for others (see Table 8). 
Table 4

Regression Model 1

\begin{tabular}{|c|c|c|c|c|}
\hline \multicolumn{5}{|c|}{ Dependent variable: PDRB } \\
\hline \multicolumn{5}{|l|}{ Heterogeneous } \\
\hline Variable & Coefficient & Std. error & $t$-statistic & Prob. \\
\hline $\operatorname{PAD}^{*}(\mathrm{~T}=1)$ & 1.330602 & 0.719232 & 1.850032 & $0.0684^{*}$ \\
\hline $\operatorname{PAD}^{*}(\mathrm{~T}=2)$ & -4.84505 & 1.218081 & -3.977608 & $0.0002^{* * *}$ \\
\hline $\operatorname{PAD}^{*}(\mathrm{~T}=3)$ & 0.985369 & 0.883918 & 1.114774 & 0.2687 \\
\hline $\operatorname{TRAN}^{*}(\mathrm{~T}=1)$ & -3.292278 & 1.048029 & -3.141401 & $0.0024^{* * *}$ \\
\hline $\operatorname{TRAN}^{*}(\mathrm{~T}=2)$ & 4.7333 & 1.266402 & 3.737598 & $0.0004^{* * *}$ \\
\hline $\operatorname{TRAN}^{*}(\mathrm{~T}=3)$ & -2.134791 & 1.176111 & -1.815127 & $0.0737^{*}$ \\
\hline $\mathrm{TK}^{*}(\mathrm{~T}=1)$ & -0.389057 & 0.867886 & -0.448282 & 0.6553 \\
\hline $\mathrm{TK}^{*}(\mathrm{~T}=2)$ & 2.665201 & 1.170134 & 2.277689 & $0.0257^{* *}$ \\
\hline $\mathrm{TK}^{*}(\mathrm{~T}=3)$ & -0.443985 & 0.962141 & -0.461456 & 0.6459 \\
\hline $\mathrm{T}=1$ & 66.13673 & 22.99414 & 2.876243 & 0.0053 \\
\hline $\mathrm{T}=2$ & -31.76517 & 22.95487 & -1.38381 & 0.1707 \\
\hline $\mathrm{T}=3$ & 43.90874 & 22.98958 & 1.909941 & 0.0601 \\
\hline$R$-squared & 0.331564 & \multicolumn{2}{|c|}{ S.E. of regression } & 3.080902 \\
\hline Adjusted $R$-squared & 0.229442 & \multicolumn{2}{|c|}{ Durbin-Watson stat. } & 2.316628 \\
\hline \multicolumn{5}{|l|}{ Homogen } \\
\hline Variable & Coefficient & Std. Error & t-Statistic & Prob. \\
\hline $\mathrm{C}$ & 30.57222 & 14.58017 & 2.096835 & 0.0392 \\
\hline PAD & 0.109061 & 0.591036 & 0.184525 & 0.8541 \\
\hline TRAN & -0.840625 & 0.687471 & -1.222780 & 0.2250 \\
\hline TK & -0.266874 & 0.630142 & -0.423515 & 0.6731 \\
\hline$R$-squared & 0.037176 & \multicolumn{2}{|c|}{ S.E. of regression } & 3.507864 \\
\hline Adjusted $R$-squared & 0.001070 & \multicolumn{2}{|c|}{ Durbin-Watson stat. } & 2.869526 \\
\hline$F$-statistic & 1.029628 & \multicolumn{2}{|c|}{$\operatorname{Prob}(F$-statistic $)$} & 0.384052 \\
\hline
\end{tabular}

Notes. ${ }^{*},{ }^{* *},{ }^{* * *}: p<0.10, p<0.05, p<0.1$; Source: From the authors'own data.

Table 5

Wald Test Analysis for the Effect of Real Regional Income to Growth

\begin{tabular}{llll}
\hline Test statistic & Value & $d f$ & Probability \\
\hline F-statistic & 10.20186 & $(2,72)$ & 0.0001 \\
Chi-square & 20.40372 & 2.0000 & 0.0000 \\
\hline
\end{tabular}

Note. Source: From the authors'own data.

Table 6

Wald Test Analysis for the Effect of Transfer Revenue to Growth

\begin{tabular}{llll}
\hline Test Statistic & Value & $d f$ & Probability \\
\hline F-statistic & 13.00669 & $(2,72)$ & 0.0000 \\
Chi-square & 26.01339 & 2 & 0.0000 \\
\hline
\end{tabular}

Note. Source: From the authors'own data.

All variables are significant, except for TRAN (1st year). In addition, Durbin-Watson stat. in model 2 is below 1.3, which means autocorrelation may exist. Thus, the model cannot be a benchmark for future estimate. 
Table 7

Wald Test Analysis for the Effect of Labor to Growth

\begin{tabular}{llll}
\hline Test statistic & Value & $d f$ & Probability \\
\hline F-statistic & 2.656973 & $(2,72)$ & 0.077 \\
Chi-square & 5.313946 & 2 & 0.0702 \\
\hline
\end{tabular}

Note. Source: From the authors'own data.

Table 8

Regression Model 2

\begin{tabular}{|c|c|c|c|c|}
\hline \multicolumn{5}{|c|}{ Dependent variable: MISK } \\
\hline \multicolumn{5}{|l|}{ Heterogeneous } \\
\hline Variable & Coefficient & Std. error & $t$-statistic & Prob. \\
\hline $\operatorname{PAD}^{*}(T=1)$ & -5.001555 & 1.269876 & -3.938617 & $0.000^{* * *}$ \\
\hline $\operatorname{PAD}^{*}(\mathrm{~T}=2)$ & -12.61667 & 2.150644 & -5.866463 & $0.000^{* * *}$ \\
\hline $\operatorname{PAD}^{*}(\mathrm{~T}=3)$ & -7.491853 & 1.560646 & -4.800482 & $0.000^{* * *}$ \\
\hline $\operatorname{TRAN}^{*}(\mathrm{~T}=1)$ & 1.571917 & 1.850399 & 0.849501 & 0.398 \\
\hline $\operatorname{TRAN}^{*}(\mathrm{~T}=2)$ & 8.165463 & 2.235959 & 3.651884 & $0.001^{* * *}$ \\
\hline $\operatorname{TRAN}^{*}(\mathrm{~T}=3)$ & 3.81378 & 2.076542 & 1.836602 & $0.070^{*}$ \\
\hline $\mathrm{TK}^{*}(\mathrm{~T}=1)$ & 3.541345 & 1.53234 & 2.31107 & $0.024^{* *}$ \\
\hline $\mathrm{TK}^{*}(\mathrm{~T}=2)$ & 9.403589 & 2.065989 & 4.551617 & $0.000^{* * *}$ \\
\hline $\mathrm{TK}^{*}(\mathrm{~T}=3)$ & 5.137805 & 1.698756 & 3.024451 & $0.004^{* * *}$ \\
\hline $\mathrm{T}=1$ & 53.8119 & 40.59846 & 1.325467 & 0.189 \\
\hline $\mathrm{T}=2$ & -8.162718 & 40.52911 & -0.201404 & 0.841 \\
\hline $\mathrm{T}=3$ & 33.24593 & 40.59041 & 0.819059 & 0.416 \\
\hline$R$-squared & 0.522182 & \multicolumn{2}{|c|}{ S.E. of regression } & 5.43964 \\
\hline Adjusted $R$-squared & 0.449182 & \multicolumn{2}{|c|}{ Durbin-Watson stat. } & 0.727568 \\
\hline \multicolumn{5}{|l|}{ Homogen } \\
\hline Variable & Coefficient & Std. error & $t$-statistic & Prob. \\
\hline PAD & -6.893961 & 0.916109 & -7.525260 & $0.0000^{* * *}$ \\
\hline TRAN & 3.547731 & 1.182173 & 3.001024 & $0.0036^{* * *}$ \\
\hline TK & 4.583635 & 0.978910 & 4.682386 & $0.0000^{* * *}$ \\
\hline$R$-squared & 0.431240 & \multicolumn{2}{|c|}{ S.E. of regression } & 5.630212 \\
\hline Adjusted $R$-squared & 0.409912 & \multicolumn{2}{|c|}{ Durbin-Watson stat. } & 0.542287 \\
\hline$F$-statistic & 20.21898 & \multicolumn{2}{|c|}{$\operatorname{Prob}(F$-statistic $)$} & 0.000000 \\
\hline
\end{tabular}

Notes. ${ }^{*},{ }^{* *},{ }^{* * *}: p<0.10, p<0.05, p<0.1$; Source: From the authors'own data.

Model 2 with simple data panel regression is significant (at 5\%) with 0.4 adjusted $R$-squared. All variables are significant, and only PAD has negative coefficient to MISK which is similar to the heterogeneous model.

\section{Conclusions}

From the regression analysis, the result shows that TRAN has the most significant effect on PDRB in each year and have positive effect on PDRB in 2009, then followed by PAD except for the 3rd year (positive effect only in 2008, the same with TK). The simple regression model did not show good model. PAD has negative effect on MISK and have the same significant effect each year. While TRAN and TK have positive effect on MISK, all were significant except for TRAN in 2009. The simple model has similar coefficient sign to the heterogeneous model. 
It gives conclusion that the revenue transfer from central government still has the important role for the development of the local government, while with the efforts from the local government to bring the idea of as much real regional income to get will decrease the poverty in the region.

\section{References}

Agung, I. G. N. (2006). Statistika. Jakarta: Yayasan SAD Satria Bhakti.

Hamzah, A. (2009). Pengaruh Pendapatan Asli Daerah, dana perimbangan dan belanja publik terhadap pertumbuhan ekonomi, kemiskinan dan pengangguran. Pendekatan analisis jalur (Studi pada 38 Kota/Kabupaten di Provinsi Jawa Timur periode 2001 - 2006). Jurnal Akutansi dan Keuangan Indonesia, 4(2), 211-228.

Indrawan, R. D. (2011). Teori anggaran dan sistem anggaran di Indonesia. Retrieved from http://www.scribd.com/doc/68354866/Teori-Anggaran-dan-Sistem-Anggaran

Kaspuri. (2007). Pengaruh pengeluaran Pemerintah daerah terhadap pertumbuhan ekonomi regional di Indonesia (Master thesis, Universitas Indonesia).

Ministry of Law and Human Rights. (2005). Government regulation No. 24/2005 on Governmental accounting standard. Republic of Indonesia

Omposungu, Z. (2010). Analisis pengaruh realisasi pendapatan dan belanja daerah terhadap pertumbuhan ekonomi daerah (studi pada 8 kabupaten dan kota di Sumatera Utara) (Master thesis, Universitas Sumatera Utara). Retrieved from http://repository.usu.ac.id/bitstream/123456789/21502/6.pdf

Palupi, E. D. (2009). Pengaruh Pendapatan Asli Daerah dan dana perimbangan terhadap pertumbuhan ekonomi di era desentralisasi Fiskal (studi kasus di jawa tengah) (Master thesis, Universitas Indonesia).

Pusporini, D. (2006). Pengaruh dana perimbangan terhadap pertumbuhan ekonomi di Indonesia. Retrieved from http://garuda.dikti.go.id/jurnal/detil/id/0:17530/q/pengarang:\%20Indah

Siregar, H. (2006). Dampak pertumbuhan ekonomi terhadap penurunan jumlah penduduk miskin. Retrieved from http://pse.litbang.deptan.go.id/ind/pdffiles/Siregar21agts07.pdf

Siregar, H., \& Wahyuniarti, D. (2007). Dampak pertumbuhan ekonomi terhadap penurunan jumlah penduduk miskin. Retrieved from http://www.brighten.or.id/brighten/index.php/component/attachments/download/18

State Secretary. (1999). Act No. 22/1999 on Local government. Republic of Indonesia

State Secretary. (2004). Act No. 32/2004 on Local government (revised). Republic of Indonesia

State Secretary. (2004). Act No. 33/2004 on Financial balanced between central and local government. Republic of Indonesia

Wijayanto, R. D. (2010). Analisis pengaruh PDRB, pendidikan dan pengangguran terhadap kemiskinan di kabupaten/kota Jawa Tengah Tahun 2005-2008. Retrieved from http://eprints.undip.ac.id/23008/1/SKRIPSI.PDF 